\title{
Potential of Vegetable E-Commerce for Empowering Farmers in Indonesia
}

\author{
Atika Dian Pitaloka ${ }^{1 *}$, Hartoyo ${ }^{2}$, Mochammad Mukti Ali $^{3}$ \\ ${ }^{1}$ School of Business Institut Pertanian Bogor, Indonesia (atikadiann@yahoo.com) \\ ${ }^{2}$ School of Business Institut Pertanian Bogor, Indonesia (hartoyo@apps.ipb.ac.id) \\ 3University of Mercubuana, Indonesia (mukti_gte@yahoo.com)
}

\begin{abstract}
The Covid-19 pandemic has disrupted the flow of horticultural products from farmers to consumers. It causes the delivery of vegetables to be hampered, especially in Jabodetabek, which is the center of vegetable consumption. Therefore, a new marketing strategy is needed involving e-commerce to meet people's need for vegetables. This study discusses the buying behavior of vegetables through e-commerce in Jabodetabek and analyzes the role of $e$ commerce platforms to empower farmers in Indonesia. The method used in this research is descriptive qualitative with two data sources, primary data obtained from questionnaires filled out by 153 respondents and secondary data obtained from literature studies. The results showed that 50.33 percent of respondents prefer to shop for vegetables through e-commerce, and 51.63 percent think online vegetable shopping services are better than offline or conventional shopping. The majority of people choose to buy vegetables online through e-commerce because of concerns about the spread of the COVID-19 virus. However, vegetable purchasing behavior is still in the introduction stage. E-commerce plays a role in making it easier for people to get the needs of quality vegetables at competitive prices. Empowering farmers to produce high-quality products is very important in increasing consumer repurchase intentions and improving the welfare of farmers in Indonesia.
\end{abstract}

Keywords: Vegetable e-commerce; repurchase intention; farmer empowerment; consumer behaviour; attitude

\section{ABSTRAK}

Adanya pandemi Covid-19 menyebabkan gangguan arus produk hortikultura dari petani ke konsumen. Hal tersebut menyebabkan pengiriman sayuran terhambat terutama di Jabodetabek yang merupakan pusat konsumsi sayuran. Oleh karena 
itu diperlukan strategi pemasaran baru melibatkan e-commerce demi memenuhi kebutuhan masyarakat akan sayuran. Penelitian ini membahas mengenai perilaku pembelian ulang sayuran melalui e-commerce di Jabodetabek dan menganalisis peran platform e-commerce untuk memberdayakan petani di Indonesia. Metode yang digunakan dalam penelitian ini yaitu kualitatif deskriptif dengan dua sumber data, yaitu data primer yang diperoleh dari kuesioner yang diisi oleh 153 responden dan data sekunder yang diperoleh dari studi literatur. Hasil penelitian menunjukkan bahwa sebesar 50.33 persen responden lebih suka berbelanja sayuran melalui e-commerce dan 51.63 persen diantaranya menganggap layanan berbelanja sayuran secara online lebih baik dibandingkan cara berbelanja offline atau konvensional. Mayoritas masyarakat memilih membeli sayuran secara online melalui e-commerce karena kekhawatiran akan penyebaran virus covid-19. Namun perilaku pembelian sayuran masih dalam tahap pengenalan. E-commerce berperan dalam memudahkan masyarakat mendapatkan kebutuhan sayuran berkualitas dengan harga yang kompetitif. Memberdayakan petani untuk dapat menghasilkan produk berkualitas tinggi menjadi sangat penting dalam meningkatkan niat beli ulang konsumen serta menyejahterakan petani di Indonesia.

Kata kunci: E-commerce sayuran; niat beli ulang; pemberdayaan petani; perilaku konsumen; sikap

\section{INTRODUCTION}

The Covid-19 pandemic has caused human activities to become more limited than before, especially with the enactment of government regulations such as Large-Scale Social Restrictions (PSBB), Micro and Community-Scale Social Restrictions (PSBMK), and the Enforcement of Community Activity Restrictions (PPKM). It disrupts the flow of horticultural products, including vegetables, so that e-commerce is needed as a marketing tool so that people can meet their needs. Changing consumer behavior is not easy, even though the current conditions support the shifting behavior. Based on interviews conducted by CNN Indonesia to several communities in 2018, some people say they are reluctant to buy vegetables online because they cannot see the freshness of the vegetable products that they purchased, and they have to wait a few days for the products to arrive at consumers (CNN Indonesia, 2018). It indicates that people are worried about the quality of vegetable products sold by online systems through e-commerce. Nevertheless, technology that is easy to use, useful and reliable is thought to increase the intention to buy vegetables through ecommerce platforms in Jabodetabek. Therefore, the variables perceived ease of use, perceived usefulness, trust, attitude, satisfaction, and repurchase intention will be investigated.

One economic sector that absorbs the most labor in 2021 is the agricultural sector. However, this is not due to the attractiveness of the agricultural sector, but because the demand for the quality of human resources in the agricultural sector is not as high as in the other sectors. The low quality of workers in the agricultural sector can result in less than optimal farming operations, which affects the quality of the vegetables produced. The quality of workers in the agricultural 
sector must be improved through farmer empowerment activities. Empowerment of farmers is an effort to increase the knowledge and competence of farmers in doing farming. Farmer empowerment is an activity that involves the participation and leadership of empowered farmer groups (Hermanto and Swastika, 2011). With empowered farmers, the quality of vegetable products produced will also be better so as to overcome consumer concerns. During the Covid-19 pandemic, the Farmer's Exchange Rate (NTP) in May 2021 experienced a high increase, which was 103.39\% or up $0.44 \%$ compared to the previous month, and the NTUP in May 2021 reached $104.04 \%$ or higher than May 2020, which is only 100.16\% (Mediaindonesia, 2021). The increase in farmers' NTP and NTUP is proof that the agricultural sector is growing during the Covid-19 pandemic, and this opportunity must be utilized as well as possible by e-commerce through empowering farmers in providing quality vegetable products so that people are willing to buy vegetables online through e-commerce despite the end of the Covid-19 pandemic.

This research was conducted to develop a Technology Acceptance Model (TAM) where previous studies only focused on the acceptance of mobile e-commerce technology models (Rachbini et al., 2019), mobile banking (Kurniawan et al., 2013), e-learning (Correa et al., 2015), and information communication technology (Salman et al., 2014). This study seeks to add satisfaction as one of the variables studied. The addition of another variable, namely trust, also plays a role in developing TAM theory. It can be said to be the development of several previous studies. This research also focuses on the Theory of Reasoned Action (TRA) as a basis for development in further studies. This research does not look at the relationship between variables but studies what indicators influence building a variable or construct. Research with variables of perceived usefulness, perceived ease of use, attitude, trust, satisfaction, and repurchase intention is still minimal, especially for vegetable commodities. This research was conducted to complement various studies in the field of repurchase intentions of vegetable commodities through ecommerce. This research is expected to be an input for e-commerce business actors who market vegetables using technology to determine effective and efficient marketing strategy policies. This research is also helpful for the world of education as a benchmark or guideline to find out the factors that influence consumers' repurchase intentions and library material for further research.

\section{METHOD}

Data collection in this study was carried out from March to April 2021, with the respondents being people who live in Jabodetabek. In this study, the respondents were Jabodetabek people who had purchased vegetables online through e-commerce which were individual sellers. The variables used for the qualitative research are perceived ease of use, perceived usefulness, trust, attitude, satisfaction, and repurchase intention using the top two boxes test. The total number of respondents used in this study amounted to 153 people. This research is descriptive qualitative. Descriptive research is intended to measure carefully certain social phenomena, in this study related to the phenomenon of determinants of consumer satisfaction with a product and the factors that influence it (Kotler, 2002). The method used in this study is a survey method using a questionnaire that is distributed online via WhatsApp. Based on data collection techniques in this study, using two data sources, primary data, and secondary data. Primary data is data obtained directly from the source or object of research. The primary data in this study came from the results of a questionnaire that had been filled out by the respondent. Meanwhile, the secondary data used 
in this study is a literature study either from journals, books, news in the mass media, or other information related to research. This research does not look at the relationship between variables but studies what indicators influence building a variable or construct.

\section{RESULTS AND DISCUSSION}

\subsection{Based on the Characteristics of Respondents}

Respondents in this study amounted to 153 people spread over five cities: Jakarta, Bogor, Depok, Tangerang, and Bekasi. The respondents' characteristics in this study include demographic characteristics, social characteristics, economic characteristics, perceptions of vegetables sold through e-commerce, and the level of intensity in purchasing vegetables online through ecommerce.

Table 1. Respondent demographic statistics

\begin{tabular}{|c|c|c|c|}
\hline \multicolumn{2}{|c|}{ Respondent Characteristics } & Frequency of Respondents & Percentage $(\%)$ \\
\hline \multirow[t]{4}{*}{ Age } & $18-26$ years old & 22 & 14,38 \\
\hline & $27-40$ years old & 106 & 69,28 \\
\hline & 41 - 56 years old & 20 & 13,07 \\
\hline & $>56$ years old & 5 & 3,27 \\
\hline \multirow[t]{2}{*}{ Gender } & Female & 113 & 73,86 \\
\hline & Male & 40 & 26,14 \\
\hline \multirow[t]{5}{*}{ Level of Education } & Senior high school & 12 & 7,84 \\
\hline & Associate degree & 12 & 7,84 \\
\hline & Bachelor degree & 85 & 55,56 \\
\hline & Master degree & 42 & 27,45 \\
\hline & Doctoral degree & 2 & 1,31 \\
\hline \multirow[t]{3}{*}{ Marital status } & Single & 34 & 22,22 \\
\hline & Married & 116 & 75,82 \\
\hline & Widow/widower & 3 & 1,96 \\
\hline \multirow[t]{5}{*}{ Domicile } & Jakarta & 34 & 22,22 \\
\hline & Bogor & 41 & 26,80 \\
\hline & Depok & 26 & 16,99 \\
\hline & Tangerang & 26 & 16,99 \\
\hline & Bekasi & 26 & 16,99 \\
\hline \multirow[t]{9}{*}{ Profession } & Entrepreneur & 3 & 1,96 \\
\hline & Private sector employee & 34 & 22,22 \\
\hline & BUMN employees & 32 & 20,92 \\
\hline & Housewife & 24 & 15,69 \\
\hline & PNS/TNI/POLRI & 25 & 16,34 \\
\hline & Service worker/freelancer & 1 & 0,65 \\
\hline & Professional & 3 & 1,96 \\
\hline & $\begin{array}{l}\text { Lecturers/teachers } \\
\text { /government employees }\end{array}$ & 18 & 11,76 \\
\hline & Others & 13 & 8,50 \\
\hline \multirow[t]{4}{*}{ Income } & $<3.5$ million & 26 & 16,99 \\
\hline & 3.5 - 7 million & 43 & 28,10 \\
\hline & $>7$ - 14 million & 52 & 33,99 \\
\hline & $>14$ million & 32 & 20,92 \\
\hline
\end{tabular}

Source: Primary data (processed data) 
The majority of respondents in this study are millennials (gen Y), in the age range of 27 - 40 years are 69.28 percent. It indicates that the millennial generation is more responsive to new technology and desires to try it. Based on the gender of the respondents in this study, it was found that the distribution of female respondents was 73.86 percent and the distribution of male respondents was 26.14 percent. These results indicate that vegetable consumers in e-commerce are dominated by women who are more concerned about spending on vegetables for daily consumption. Women are a suitable target market for marketing vegetables through e-commerce.

Education level is one of the dominant factors influencing a person's behavior. In this study, the total respondents who received higher education from D3 to S3 were 92.16 percent. A high level of education makes a person understand the importance of consuming vegetables and has a high enough purchasing power to influence purchase intentions.

Married respondents dominate in this study by 75.82 percent. This result is higher than respondents who are unmarried (single) and widows or widowers. This is because married respondents have an interest in shopping for daily needs, including vegetables. Respondents in this study were dominated by 26.80 percent from Bogor city, 22.22 percent from Jakarta, while respondents who lived in Depok, Tangerang, and Bekasi had the same percentage of 16.99 percent.

Private and BUMN employees dominate the respondents' livelihoods at 22.22 percent and 20.92 percent. It indicates that private employees and BUMN have higher purchasing power compared to other livelihoods. Regarding income level, respondents in this study were dominated by respondents with income $>$ Rp $7-14$ million, amounting to 33.99 percent. The respondent's income level can reflect consumers' purchasing power to try something new at a higher cost.

Table 2. Vegetable shopping behavior through e-commerce

\begin{tabular}{|c|c|c|c|}
\hline \multicolumn{2}{|c|}{ Respondent Characteristics } & Frequency of Respondents & Percentage $(\%)$ \\
\hline \multirow[t]{5}{*}{ Initiative } & Self & 126 & 82,35 \\
\hline & Couple & 16 & 10,46 \\
\hline & Child & 3 & 1,96 \\
\hline & Parent & 6 & 3,92 \\
\hline & Other & 2 & 1,31 \\
\hline \multirow{3}{*}{$\begin{array}{l}\text { How long is your experience in using e- } \\
\text { commerce to shop vegetables? }\end{array}$} & $<1$ year & 83 & 54,25 \\
\hline & $1-2$ years & 42 & 27,45 \\
\hline & $>2$ years & 28 & 18,30 \\
\hline \multirow[t]{6}{*}{ Which e-commerce do you use the most? } & Sayurbox & 103 & 67,32 \\
\hline & Brambang & 3 & 1,96 \\
\hline & Kedaimart & 3 & 1,96 \\
\hline & Tanihub & 13 & 8,50 \\
\hline & Tukangsayur.co & 7 & 4,58 \\
\hline & Other & 24 & 15,69 \\
\hline \multirow{2}{*}{$\begin{array}{l}\text { Have you ever switched e-commerce } \\
\text { because of disappointment or } \\
\text { dissatisfaction with e-commerce before? }\end{array}$} & Yes & 46 & 30,07 \\
\hline & No & 107 & 69,93 \\
\hline $\begin{array}{l}\text { If your chosen e-commerce meets your } \\
\text { expectations, are you interested in trying }\end{array}$ & Yes & 115 & 75,16 \\
\hline $\begin{array}{l}\text { other e-commerce that you have never } \\
\text { used at all? }\end{array}$ & No & 38 & 24,84 \\
\hline
\end{tabular}




\begin{tabular}{|c|c|c|c|}
\hline \multicolumn{2}{|c|}{ Respondent Characteristics } & \multirow{2}{*}{$\begin{array}{c}\text { Frequency of Respondents } \\
127\end{array}$} & \multirow{2}{*}{$\frac{\text { Percentage }(\%)}{83,01}$} \\
\hline What products do you usually buy in & Vegetables & & \\
\hline vegetable e-commerce? (Answers can be & Fruits & 114 & 74,51 \\
\hline \multirow{6}{*}{ more than 1) } & Animal protein & 57 & 37,25 \\
\hline & Vegetable protein & 35 & 22,88 \\
\hline & Herbs & 45 & 29,41 \\
\hline & Food & 16 & 10,46 \\
\hline & Drink & 11 & 7,19 \\
\hline & Other & 6 & 3,92 \\
\hline \multirow{3}{*}{$\begin{array}{l}\text { What vegetable products do you buy the } \\
\text { most in horticultural e-commerce? }\end{array}$} & Fruit vegetables & 71 & 46,41 \\
\hline & Leaf vegetables & 46 & 30,07 \\
\hline & Root vegetables & 36 & 23,53 \\
\hline \multirow{3}{*}{$\begin{array}{l}\text { How many kinds of vegetable products } \\
\text { do you buy in one transaction? }\end{array}$} & $1-5$ kinds & 116 & 75,82 \\
\hline & $>5-10$ kinds & 32 & 20,92 \\
\hline & $>10$ kinds & 5 & 3,27 \\
\hline \multirow{3}{*}{$\begin{array}{l}\text { How many times have you bought } \\
\text { vegetables using e-commerce in the last } \\
\text { month? }\end{array}$} & $1-2$ & 121 & 79,08 \\
\hline & $3-4$ & 28 & 18,30 \\
\hline & $5-6$ & 4 & 2,61 \\
\hline \multirow{3}{*}{$\begin{array}{l}\text { How is the quality of the vegetables you } \\
\text { buy? }\end{array}$} & Low & 0 & 0,00 \\
\hline & Medium & 108 & 70,59 \\
\hline & Premium & 45 & 29,41 \\
\hline \multirow{3}{*}{$\begin{array}{l}\text { How often do you use e-commerce to } \\
\text { shop for vegetables? }\end{array}$} & Sometimes & 123 & 80,39 \\
\hline & Often & 26 & 16,99 \\
\hline & Always & 4 & 2,61 \\
\hline \multirow{2}{*}{$\begin{array}{l}\text { Do you intend to continue buying } \\
\text { vegetables online through e-commerce } \\
\text { after the Covid-19 pandemic ends? }\end{array}$} & Yes & 110 & 71,90 \\
\hline & No & 43 & 28,10 \\
\hline \multirow{6}{*}{$\begin{array}{l}\text { What is the main reason you shop for } \\
\text { vegetables online? }\end{array}$} & Ease of shopping & 51 & 33,33 \\
\hline & Saving time & 30 & 19,61 \\
\hline & $\begin{array}{l}\text { Want to avoid crowds } \\
\text { especially during the } \\
\text { Covid- } 19 \text { pandemic }\end{array}$ & 52 & 33,99 \\
\hline & $\begin{array}{l}\text { I like using technology } \\
\text { to help my activities }\end{array}$ & 13 & 8,50 \\
\hline & $\begin{array}{l}\text { Online vegetable e- } \\
\text { commerce is more } \\
\text { trustworthy }\end{array}$ & 4 & 2,61 \\
\hline & $\begin{array}{l}\text { Provides higher } \\
\text { satisfaction than } \\
\text { conventional shopping }\end{array}$ & 3 & 1,96 \\
\hline
\end{tabular}

Source: Primary data (processed data)

From Table 2 above, it can be seen that the majority of respondents have their own initiative in purchasing vegetables online through e-commerce by 82.35 percent. This indicates that most of the respondents have complete control over behavior. Most of the respondents, 54.25 percent, have experience shopping vegetables through e-commerce $<1$ year. It means that most respondents only started shopping for vegetables online during the COVID-19 pandemic. This result aligns with the main reason respondents shop for vegetables online. As many as 33.99 percent of respondents shop for vegetables online because they want to avoid crowds, especially during the covid-19 pandemic. As many as 71.90 percent of respondents intend to continue shopping for vegetables online after the COVID-19 pandemic ends.

E-commerce that has the most frequently used is Sayurbox, which is a pioneer in vegetable ecommerce with a gain of 67.32 percent. A total of 69.93 percent of respondents said they had never switched to e-commerce. In comparison, another 30.07 percent had switched to e-commerce 
for various reasons. The most purchased vegetable products were fruit vegetables by 46.41 percent, leaf vegetables by 30.07 percent, and tuber vegetables by 23.53 percent.

As many as 75.82 percent of respondents buy 1-5 kinds of products in each transaction, 20.92 percent of respondents buy $>$ 5-10 kinds. In comparison, only 3.27 percent of respondents buy $>10$ kinds. It is most likely due to the perishable nature of vegetable products. Vegetables cannot last long without proper handling, so most respondents choose to make purchases gradually or little by little according to their needs.

A total of 79.08 percent of respondents only made purchases of vegetables through ecommerce as much as 1-2 times in the past month. These results indicate that they do not often shop for vegetables online and only shop for specific reasons. This is supported by data that 80.39 percent of the total respondents stated that they only buy vegetables through e-commerce occasionally. Only 16.99 percent frequently make purchases, and 2.61 percent always shop for vegetables through e-commerce.

Respondents' perceptions of the quality of vegetable products they received tend to be moderate. A total of 70.59 percent of respondents feel that the quality of vegetable products is medium. Only 29.41 percent of respondents feel that the quality of the vegetable products they receive is a premium product.

Table 3. Vegetable shopping behavior based on expenditure

\begin{tabular}{llcc}
\hline \multicolumn{1}{c}{ Respondent Characteristics } & Frequency of Respondents & Percentage $(\%)$ \\
\hline How much do you spend in buying & $\leq 50.000$ & 6 & 3,92 \\
vegetables online through e-commerce in & $>50.000-100.000$ & 65 & 42,48 \\
1 transaction? & $>100.000-150.000$ & 43 & 28,10 \\
& $>150.000-200.000$ & 22 & 14,38 \\
& $>200.000$ & 17 & 11,11 \\
\hline How much do you spend in buying & $\leq 100.000$ & 35 & 22,88 \\
vegetable products online through e- & $>100.000-200.000$ & 55 & 35,95 \\
commerce in 1 month? & $>200.000-400.000$ & 46 & 30,07 \\
& $>400.000-600.000$ & 5,88 \\
& $>600.000$ & 5 & 5,23 \\
\hline How much do you spend in buying & $\leq 50.000$ & 8 & 23,53 \\
vegetables conventionally (offline) in 1 & $>50.000-100.000$ & 36 & 44,44 \\
transaction? & $>100.000-150.000$ & 68 & 13,73 \\
& $>150.000-200.000$ & 21 & 9,15 \\
& $>200.000$ & 14 & 9,15 \\
\hline How much do you spend in buying & $\leq 100.000$ & 14 & 13,73 \\
vegetables conventionally (offline) in 1 & $>100.000-200.000$ & 21 & 26,80 \\
month? & $>200.000-400.000$ & 41 & 26,80 \\
& $>400.000-600.000$ & 41 & 12,42 \\
& $>600.000$ & 19 & 20,26 \\
\hline What is the highest purchase rupiah you & $\leq 50.000$ & 31 & 3,92 \\
have ever made in shopping for & $>50.000-100.000$ & 6 & 24,18 \\
vegetables through e-commerce in 1 & $>100.000-150.000$ & 37 & 24,18 \\
transaction? & $>150.000-200.000$ & 37 & 22,88 \\
& $>200.000$ & 35 & 24,84 \\
\hline
\end{tabular}

As many as 42.48 percent respondents spent > IDR 50,000 - IDR 100,000 in one transaction. It means that most respondents make purchases in relatively small quantities. This could be due to the perishable nature of agricultural products and low shelf life, which made respondents unable to make purchases in large quantities. Meanwhile, 35.95 percent of respondents have expenses for 
shopping vegetables online through e-commerce in one month of > IDR 100,000 - IDR 200,000. This data shows that most respondents made purchases of vegetables through e-commerce two times within one month.

\subsection{Results of Top Two Boxes Test Analysis}

\section{Perceived ease of use}

The perceived ease of use variable consists of three indicators: PEU1, PEU2, and PEU3. Based on the calculation of the top two boxes presented in Table 4, it is known that 84.97 percent of respondents agree that the shopping method is easy to understand, less effort, and easy to use skillfully.

Table 4. Distribution of respondents based on indicators of perceived ease of use

\begin{tabular}{|c|c|c|c|c|c|c|c|c|}
\hline Symbol & Indicator & $\begin{array}{l}\text { Strongly } \\
\text { disagree }\end{array}$ & Disagree & $\begin{array}{c}\text { Just } \\
\text { agree }\end{array}$ & Agree & $\begin{array}{l}\text { Strongl } \\
\text { y agree }\end{array}$ & $\begin{array}{l}\text { Top two } \\
\text { boxes }\end{array}$ & $\%$ \\
\hline PEU1 & $\begin{array}{l}\text { Shop through e-commerce is easy to } \\
\text { understand }\end{array}$ & 0 & 6 & 10 & 81 & 56 & 137 & 89,54 \\
\hline PEU2 & $\begin{array}{l}\text { Shopping for vegetables online requires } \\
\text { less effort }\end{array}$ & 1 & 5 & 29 & 93 & 25 & 118 & 77,12 \\
\hline PEU3 & $\begin{array}{l}\text { It's easy for me to be skilled at using e- } \\
\text { commerce applications }\end{array}$ & 1 & 4 & 13 & 63 & 72 & 135 & 88,24 \\
\hline
\end{tabular}

\section{Perceived usefulness}

The perceived usefulness variable consists of four indicators: PU1, PU2, PU3, and PU4. Based on the calculation of the top two boxes presented in Table 5, it is known that 89.38 percent of respondents agree that e-commerce makes it easy to shop for vegetables, has competitive prices, saves time, and has high flexibility to increase productivity.

Table 5. Distribution of respondents based on indicators of perceived usefulness

\begin{tabular}{|c|c|c|c|c|c|c|c|c|}
\hline Symbol & Indicator & $\begin{array}{l}\text { Strongly } \\
\text { disagree }\end{array}$ & Disagree & $\begin{array}{l}\text { Just } \\
\text { agree }\end{array}$ & Agree & $\begin{array}{l}\text { Strongl } \\
\text { y agree }\end{array}$ & $\begin{array}{c}\text { Top two } \\
\text { boxes }\end{array}$ & $\%$ \\
\hline PU1 & $\begin{array}{l}\text { E-commerce makes it easy for me to do } \\
\text { vegetable purchases as needed }\end{array}$ & 0 & 1 & 16 & 70 & 66 & 136 & 88,89 \\
\hline PU2 & $\begin{array}{l}\text { The price of vegetables sold through e- } \\
\text { commerce is quite competitive compared } \\
\text { to those sold conventionally in the } \\
\text { market or supermarket }\end{array}$ & 0 & 0 & 17 & 75 & 61 & 136 & 88,89 \\
\hline PU3 & $\begin{array}{l}\text { E-commerce helps me save time on } \\
\text { vegetable shopping }\end{array}$ & 0 & 2 & 15 & 69 & 67 & 136 & 88,89 \\
\hline PU4 & $\begin{array}{l}\text { Shopping using e-commerce has high } \\
\text { flexibility so that it helps me to be more } \\
\text { productive doing other things }\end{array}$ & 0 & 0 & 14 & 68 & 71 & 139 & 90,85 \\
\hline
\end{tabular}

\section{Trust}

Based on the calculation of the top two boxes presented in Table 6, it is known that 81.26 percent of respondents believe that e-commerce delivers products on time, has good business experience, willing to provide benefits to customers, able to provide the best solutions to customer complaints, able to meet expectations and trustworthy. 
Table 6. Distribution of respondents based on the trust indicator

\begin{tabular}{|c|c|c|c|c|c|c|c|c|}
\hline Symbol & Indicator & $\begin{array}{l}\text { Strongly } \\
\text { disagree }\end{array}$ & Disagree & $\begin{array}{l}\text { Just } \\
\text { agree }\end{array}$ & Agree & $\begin{array}{l}\text { Strongl } \\
\text { y agree }\end{array}$ & $\begin{array}{c}\text { Top two } \\
\text { boxes }\end{array}$ & $\%$ \\
\hline $\mathrm{T} 1$ & $\begin{array}{l}\text { I believe my chosen vegetable e- } \\
\text { commerce delivers the product on time }\end{array}$ & 1 & 0 & 34 & 74 & 44 & 118 & 77,12 \\
\hline $\mathrm{T} 2$ & $\begin{array}{l}\text { My chosen vegetable e-commerce has } \\
\text { good business experience in the field }\end{array}$ & 0 & 0 & 22 & 84 & 47 & 131 & 85,62 \\
\hline $\mathrm{T} 3$ & $\begin{array}{l}\text { I believe my choice of vegetable e- } \\
\text { commerce has the will to provide } \\
\text { benefits for customers }\end{array}$ & 0 & 1 & 28 & 86 & 38 & 124 & 81,05 \\
\hline $\mathrm{T} 4$ & $\begin{array}{l}\text { I believe my chosen vegetable e- } \\
\text { commerce can provide the best solution } \\
\text { for consumer complaints }\end{array}$ & 0 & 5 & 26 & 79 & 43 & 122 & 79,74 \\
\hline $\mathrm{T} 5$ & $\begin{array}{l}\text { I believe my choice of vegetable e- } \\
\text { commerce always meets customer } \\
\text { expectations }\end{array}$ & 0 & 5 & 29 & 85 & 34 & 119 & 77,78 \\
\hline T6 & $\begin{array}{l}\text { I trust my chosen vegetable e-commerce } \\
\text { can be trusted }\end{array}$ & & 1 & 20 & 84 & 48 & 132 & 86,27 \\
\hline
\end{tabular}

\section{Satisfaction}

The satisfaction variable consists of three indicators: S1, S2, and S3. Based on the calculation of the top two boxes presented in Table 7, it is known that 83.66 percent of respondents are satisfied with the freshness of vegetable products and services provided by vegetable e-commerce and agree that the vegetable e-commerce choice has been able to meet expectations.

Table 7. Distribution of respondents based on indicators of satisfaction

\begin{tabular}{|c|c|c|c|c|c|c|c|c|}
\hline Symbol & Indicator & $\begin{array}{l}\text { Strongly } \\
\text { disagree }\end{array}$ & Disagree & $\begin{array}{l}\text { Just } \\
\text { agree }\end{array}$ & Agree & $\begin{array}{l}\text { Strongl } \\
\text { y agree }\end{array}$ & $\begin{array}{l}\text { Top two } \\
\text { boxes }\end{array}$ & $\%$ \\
\hline S1 & $\begin{array}{l}\text { I am satisfied with the freshness of the } \\
\text { products sold in the vegetable e- } \\
\text { commerce }\end{array}$ & 0 & 4 & 23 & 89 & 37 & 126 & 82,35 \\
\hline S2 & $\begin{array}{l}\text { I am satisfied with the services provided } \\
\text { by vegetable e-commerce }\end{array}$ & 0 & 0 & 21 & 94 & 38 & 132 & 86,27 \\
\hline S3 & $\begin{array}{l}\text { The vegetable e-commerce that I use has } \\
\text { been able to meet my expectations }\end{array}$ & & 4 & 23 & 95 & 31 & 126 & 82,35 \\
\hline
\end{tabular}

\section{Attitude}

Based on the calculation of the top two boxes presented in Table 8, it is known that 71.90 percent of respondents agree that the quality of vegetables sold through e-commerce is guaranteed, the service for shopping vegetables through e-commerce is better than conventional shopping methods, prefers to use technology to shop for vegetables, utilizes technology for shopping for vegetables is very convenient and fun, looking for information on how to shop for vegetables through e-commerce, and always curious about everything new including shopping online through e-commerce. However, for indicator A2, only 51.63 percent of respondents think that online shopping for vegetables is better than offline or conventional shopping. 
Table 8. Distribution of respondents based on attitude indicators

\begin{tabular}{|c|c|c|c|c|c|c|c|c|}
\hline Symbol & Indicator & $\begin{array}{l}\text { Strongly } \\
\text { disagree }\end{array}$ & Disagree & $\begin{array}{l}\text { Just } \\
\text { agree }\end{array}$ & Agree & $\begin{array}{l}\text { Strongl } \\
\text { y agree }\end{array}$ & $\begin{array}{l}\text { Top two } \\
\text { boxes }\end{array}$ & $\%$ \\
\hline A1 & $\begin{array}{l}\text { Vegetables sold through e-commerce are } \\
\text { more guaranteed quality }\end{array}$ & 2 & 10 & 40 & 73 & 28 & 101 & 66,01 \\
\hline A2 & $\begin{array}{l}\text { Vegetable shopping services through e- } \\
\text { commerce are better than conventional } \\
\text { shopping methods }\end{array}$ & 3 & 15 & 56 & 51 & 28 & 79 & 51,63 \\
\hline A3 & $\begin{array}{l}\text { I like to use information technology to } \\
\text { shop vegetables online through e- } \\
\text { commerce }\end{array}$ & 2 & 3 & 34 & 72 & 42 & 114 & 74,51 \\
\hline A4 & $\begin{array}{l}\text { Utilizing technology to shop vegetables } \\
\text { is very convenient and fun }\end{array}$ & 1 & 4 & 17 & 84 & 47 & 131 & 85,62 \\
\hline A5 & $\begin{array}{l}\text { I am looking for information on how to } \\
\text { shop for vegetables through e-commerce }\end{array}$ & 3 & 6 & 24 & 77 & 43 & 120 & 78,43 \\
\hline A6 & $\begin{array}{l}\text { I'm always curious about everything new } \\
\text { including shopping online through e- } \\
\text { commerce }\end{array}$ & 1 & 4 & 33 & 67 & 48 & 115 & 75,16 \\
\hline & Average percentage & & & & & & & 71,90 \\
\hline
\end{tabular}

\section{Repurchase intention}

The repurchase intention variable consists of four indicators: RI1, RI2, RI3, and RI4. Based on the calculation of the top two boxes presented in Table 9, it is known that 69.12 percent of respondents are interested in repurchasing vegetables through e-commerce, will recommend ecommerce vegetables of their choice to others, prefer to buy vegetables through e-commerce rather than shopping directly at the market or supermarkets, and always ask for information about vegetable e-commerce to those who have used it. However, on the RI3 indicator, only 50.33 percent of respondents prefer shopping for vegetables through e-commerce rather than shopping directly at the market or supermarket.

Table 9. Distribution of respondents based on indicators of repurchase intention

\begin{tabular}{|c|c|c|c|c|c|c|c|c|}
\hline Symbol & Indicator & $\begin{array}{l}\text { Strongly } \\
\text { disagree }\end{array}$ & Disagree & $\begin{array}{c}\text { Just } \\
\text { agree }\end{array}$ & Agree & $\begin{array}{l}\text { Strongl } \\
\text { y agree }\end{array}$ & $\begin{array}{c}\text { Top two } \\
\text { boxes }\end{array}$ & $\%$ \\
\hline RI1 & $\begin{array}{l}\text { I am interested in re-purchasing } \\
\text { vegetable commodities through e- }\end{array}$ & 2 & 5 & 25 & 84 & 37 & 121 & 79,08 \\
\hline RI2 & $\begin{array}{l}\text { I will recommend my chosen vegetable e- } \\
\text { commerce to others }\end{array}$ & 2 & 4 & 32 & 80 & 35 & 115 & 75,16 \\
\hline RI3 & $\begin{array}{l}\text { I prefer to buy vegetables through e- } \\
\text { commerce than having to shop directly } \\
\text { at the market or supermarket }\end{array}$ & 6 & 16 & 54 & 46 & 31 & 77 & 50,33 \\
\hline RI4 & $\begin{array}{l}\text { I asked for information about vegetable e- } \\
\text { commerce to those who have used it }\end{array}$ & 2 & 14 & 27 & 76 & 34 & 110 & 71,90 \\
\hline
\end{tabular}

\subsection{Farmer Empowerment}

Mosher in Sudiyono (2001) divides agriculture into two groups, primitive agriculture, and modern agriculture. Primitive agriculture is defined as farmers who follow the methods derived from older people and do not accept innovation. Meanwhile, modern agriculture is defined as mastering plant growth, actively seeking new methods, and accepting updates (innovations) in agriculture. This kind of farmer can develop to support the agriculture economy. The low quality of 
human resources in the agricultural sector can result in less than optimal farming operations that affect the quality of the vegetables produced. The quality of workers in the agricultural sector must be improved through farmer empowerment activities.

According to Suharto (2010), empowerment is a process and a goal. As a process, empowerment is a series of activities to strengthen the power or empowerment of vulnerable groups in society, including individuals who experience poverty problems. As a goal, empowerment refers to the conditions or results to be achieved by a social change in which people who are empowered have power or have the knowledge and ability to meet their physical, economic, and social needs, such as having self-confidence, being able to convey aspirations, have a livelihood, participate in social activities, and are independent in carrying out their life tasks. Empowerment comes from the word power, namely power.

The empowerment program aims to improve the ability to do business, both from the aspect of motivation, technology, management, capital, and marketing so that they can be independent and have a strong bargaining position when dealing with strong actors, especially when dealing with other actors (Friedman et al., 1983 in Soesilowati et al., 2011). The system that is expected to maximize the empowerment of farmers is the inclusive closed-loop system. In the inclusive closedloop system, there are four main elements, (1) Farmers have access to buy the right seeds and fertilizers, (2) Assistance to farmers to implement good practice agriculture, (3) Easy access to credit from financial institutions, (4) Guaranteed purchase of farmers' products by coaching companies or off-takers (Kominfo Jatim, 2021).

According to Mardikanto and Poerwoko (2017), several strategic steps taken through empowerment are: First, increasing access to productive assets. For people who are still dominant in the people's economy, the principal productive capital is land. In addition, public access to a healthy environment that is not polluted will reduce the burden and increase community productivity. The most fundamental problem in the framework of this structural transformation is access to funds. Access to capital must be interpreted as affordability, which has two sides, namely when needed and within the ability to use it. Second, strengthening the position of people's economic transactions and business partnerships. As producers and sellers, the position and power of the people in the people's economy are very weak.

Human life is now leading to digitalization in all fields. In terms of consumer behavior, there is a shift in behavior from offline purchases to online purchases. It also applies to vegetable products. From the questionnaire results in this study, the majority of respondents, 33.99 percent of respondents, shopped for vegetables online because they were worried about the spread of the Covid-19 virus. However, 70.59 percent of respondents rated the quality of vegetables sold through e-commerce as a medium, so they only buy vegetables online sometimes when they need it. Most respondents believed that the products sold were medium. However, the price offered was more expensive than vegetables sold in markets and supermarkets. Respondents also pay more attention to the time of getting the product ordered. In online purchases, they have to wait the next day to get the ordered vegetable products. This is different from buying vegetables offline, where respondents get the goods directly. Respondents also complained about stock availability. Currently, no e-commerce guarantees stock availability. This resulted in the product ordered by the 
respondent sometimes not being delivered because it was out of stock, so that the e-commerce party refunded the fee that had been paid.

Consumer perceptions related to the quality of vegetable products sold can be changed through empowering farmers. It can be done if there is a collaboration with all related parties: ecommerce parties, farmers, academics, and financial institutions. Most farmers currently face difficulties in getting access to financing from banks. This is because their agricultural business depends on nature, so the business risk is relatively high. Most of the financial industry does not dare to finance this type of business. However, in the current digital era, farmers can use a peer-topeer lending financing industry to get capital. Peer-to-peer lending, specifically for agriculture, is usually not just rolling out funds and collecting payments but participates in monitoring the farms run by the borrowers. E-commerce parties can cooperate with peer-to-peer lending to monitor farmers in implementing good agricultural practices and select seeds that are in accordance with those sold by the company. Cooperation between e-commerce parties and farmers should be stated in a cooperation contract where farmers plant the specified seeds, harvest, and purchase according to the price agreed upon by the e-commerce party as the off-taker.

\section{CONCLUSION}

The novelty in this research is the combination of TAM and TRA theories combined with trust and satisfaction variables in formulating the selected variables. The commodities used in this study, namely vegetables, have not been widely studied regarding the factors influencing consumers' repurchase intentions on vegetable products. In this study, it was found that the indicator that has the strongest influence on the perceived ease of use variable is PEU1 with a value of $89.54 \%$, the indicator that has the biggest influence on the perceived usefulness variable is PU4 with a value of $90.85 \%$, the indicator that has the greatest influence on the trust variable is T6 with a value of $86.27 \%$, the indicator that has the highest influence on the attitude variable is A4 with a value of $85.62 \%$, the indicator that has the strongest influence on the satisfaction variable is S2 with a value of $86.27 \%$, and the indicator that has the biggest influence on the repurchase intention variable is RI1 with a value of $79.08 \%$.

The results showed that 50.33 percent of respondents prefer to shop for vegetables through ecommerce, and 51.63 percent think online vegetable shopping services are better than offline or conventional shopping. The majority of people choose to buy vegetables online through ecommerce because of concerns about the spread of the COVID-19 virus. However, vegetable purchasing behavior is still in the introduction stage. In the field of consumer behavior, as many as 71.90 percent of respondents said they would still shop for vegetables online through e-commerce after the Covid-19 pandemic ended. This indicates that the respondents are actually interested in behavioral changes in shopping for vegetables.

In terms of the most recent managerial implications, there are suggestions for vegetable ecommerce to make various improvements before the Covid-19 pandemic ends, such as organizing co-creation and collaboration events regularly every year, creating custom products according to consumer tastes, strengthening marketing through collaboration with the community and increase conversations on social media through horizontal marketing strategies where consumers act as messengers, and also by improving product quality through empowering farmers. Because it is 
feared that if e-commerce does not improve itself when the pandemic ends, consumers will return to the old habit of shopping for vegetables conventionally in markets and supermarkets.

\section{REFERENCES}

CNNIndonesia. (2018). Pengiriman Lama, Alasan Konsumen Enggan Beli Sayur Online. [Diakses pada 25 Agustus 2021]. Tersedia pada: https://www.cnnindonesia.com/gayahidup/20180104211638-282-266824/pengiriman-lama-alasan-konsumen-enggan-belisayur-online.

Correa R, Arenas-Gaitán J, Rondán-Cataluña FJ. (2015). Gender and acceptance of e-learning: a multi-group analysis based on a structural equation model among college students in Chile and Spain. PLOS ONE. 10(10). doi:10.1371/journal.pone.0140460.

Hermanto dan Swastika Dewi KS. (2011). Farmer's Groups Empowerment as an Initial Step to Farmer Welfare Improvement. Jurnal Analisis Kebijakan Pertanian. Vol 9 No. 4. Pusat Sosial Ekonomi dan Kebijakan Pertanian, Bogor.

Kominfo Jatim. (2021). Model Closed Loop, Keroyokan Bersama Pastikan Petani Dapat Harga Layak. Tersedia pada: http://kominfo.jatimprov.go.id/read/umum/model-closed-loop-keroyokanbersama-pastikan-petani-dapat-harga-layak

Kotler, Philip. (2002). Manajemen Pemasaran. Jilid kedua. (10 ${ }^{\text {th }}$ ed). Jakarta: Prenhallindo.

Kurniawan D, Semuel H, Japarianto E. (2013). Analisis penerimaan nasabah terhadap layanan mobile banking dengan menggunakan pendekatan technology acceptance model dan theory of reasoned action. Jurnal Manajemen Pemasaran. 1(1):1-13.

Mardikanto T, Poerwoko S. (2017). Pemberdayaan Masyarakat dalam Perspektif Kebijakan Publik. Cetakan keempat. Penerbit Afabeta. Bandung.

Medialndonesia. (2021). Sepanjang 2021, NTP Tinggi Tanda Kesejahteraan Petani Membaik. Tersedia pada: https://mediaindonesia.com/ekonomi/409017/sepanjang-2021-ntp-tinggitanda-kesejahteraan-petani-membaik.

Rachbini W, Salim F, Haque MG, Rahmawati E. (2019). Analisis niat pembelian ulang e-commerce mobile dengan pendekatan technology acceptance model. Jurnal Aplikasi Manajemen dan Bisnis. 5(3):530-540. doi:10.17358/jabm.5.3.530.

Salman A, Abdullah M, Aziz J, Ahmad AL, Kee CP. (2014). Remodelling Technology Acceptance Model in Explaining User Acceptence towards Information and Communication Technology. International Journal of Arts and Sciences. 7(1):159-171.

Soesilowati, Indriyanti, Widiyanto. (2011). Model Corporate Social Responsibility dalam Program Pemberdayaan Petani Hortikultura. Jurnal Ekonomi Pembangunan, Vol. 12 No. 1, juni 2011. Diakses melalui http://jurnal.ums.ac.id/index.php/JEP/article/view/209

Sudiyono A. (2001). Pemasaran Pertanian. Universitas Muhammadiyah Malang. Malang Suharto, Edi. (2010). Membangun Masyarakat Memberdayakan Rakyat. Refika Aditama, Bandung. 